NOTICE: This is the author's version of a work that was accepted for publication in Journal of Electroanalytical Chemistry. Changes resulting from the publishing process, such as peer review, editing, corrections, structural formatting, and other quality control mechanisms may not be reflected in this document. Changes may have been made to this work since it was submitted for publication. A definitive version was subsequently published in Journal of Electroanalytical Chemistry, Vol. 618, Issue 1-2. (2008). doi: 10.1016/j.jelechem.2008.02.018 


\section{The Electrochemical Oxidation of Hydrogen at Activated Platinum Electrodes in Room Temperature Ionic Liquids as Solvents}

Debbie S. Silvester ${ }^{a}$, Kristopher R. Ward $^{a}$, Leigh Aldous ${ }^{b}$, Christopher Hardacre ${ }^{b}$ and Richard G. Compton ${ }^{a *}$

a Physical and Theoretical Chemistry Laboratory, Oxford University, South Parks Road, Oxford OX1 3QZ, United Kingdom

${ }^{b}$ School of Chemistry and Chemical Engineering/QUILL, Queen's University Belfast, Belfast, Northern Ireland BT9 5AG, United Kingdom

To be submitted as an article to: the Journal of Electroanalytical Chemistry

* Corresponding author

Email: richard.compton@chem.ox.ac.uk

Tel:+44(0) 1865275413

Fax:+44(0) 1865275410 


\section{Abstract}

The oxidation of hydrogen was studied at an activated platinum microelectrode by cyclic voltammetry in the following ionic liquids: $\left[\mathrm{C}_{2} \mathrm{mim}\right]\left[\mathrm{NTf}_{2}\right], \quad\left[\mathrm{C}_{4} \mathrm{mim}\right]\left[\mathrm{NTf}_{2}\right],\left[\mathrm{N}_{6,2,2,2}\right]\left[\mathrm{NTf}_{2}\right]$, $\left[\mathrm{P}_{14,6,6,6}\right]\left[\mathrm{NTf}_{2}\right],\left[\mathrm{C}_{4} \mathrm{mim}\right][\mathrm{OTf}],\left[\mathrm{C}_{4} \mathrm{mim}\right]\left[\mathrm{BF}_{4}\right], \quad\left[\mathrm{C}_{4} \mathrm{mim}\right]\left[\mathrm{PF}_{6}\right], \quad\left[\mathrm{C}_{4} \mathrm{mim}\right]\left[\mathrm{NO}_{3}\right], \quad\left[\mathrm{C}_{6} \mathrm{mim}\right] \mathrm{Cl}$ and $\left[\mathrm{C}_{6} \mathrm{mim}\right][\mathrm{FAP}]$ (where $\left[\mathrm{C}_{n} \mathrm{mim}\right]^{+}=1$-alkyl-3-methylimidazolium, $\left[\mathrm{N}_{6,2,2,2}\right]^{+}=$n-hexyltriethylammonium, $\left[\mathrm{P}_{14,6,6,6}\right]^{+}=\operatorname{tris}\left(\mathrm{n}-\right.$ hexyltetradecyl)phosphonium, $\left[\mathrm{NTf}_{2}\right]^{-}=$bis(trifluoromethylsulfonyl)amide, $[\mathrm{OTf}]^{-}=$trifluoromethlysulfonate and $[\mathrm{FAP}]^{-}=$tris(perfluoroethyl)trifluorophosphate). Activation of the Pt electrode was necessary to obtain reliable and reproducible voltammetry. After activation of the electrode, the $\mathrm{H}_{2}$ oxidation waves were nearly electrochemically and chemically reversible in $\left[\mathrm{C}_{n} \mathrm{mim}\right]\left[\mathrm{NTf}_{2}\right]$ ionic liquids, chemically irreversible in $\left[\mathrm{C}_{6} \mathrm{mim}\right] \mathrm{Cl}$ and $\left[\mathrm{C}_{4} \mathrm{mim}\right]\left[\mathrm{NO}_{3}\right]$, and showed intermediate characteristics in $[\mathrm{OTf}]^{-},\left[\mathrm{BF}_{4}\right]^{-},\left[\mathrm{PF}_{6}\right]^{-},[\mathrm{FAP}]^{-}$ and other $\left[\mathrm{NTf}_{2}\right]^{-}$-based ionic liquids. These differences reflect the contrasting interactions of protons with the respective RTIL anions. The oxidation peaks are reported relative to the half-wave potential of the cobaltocenium/cobaltocene redox couple in all ionic liquids studied, giving an indication of the relative proton interactions of each ionic liquid. A preliminary temperature study ( $c a .298-333 \mathrm{~K}$ ) has also been carried out in some of the ionic liquids. Diffusion coefficients and solubilities of hydrogen at $298 \mathrm{~K}$ were obtained from potential-step chronoamperometry, and there was no relationship found between the diffusion coefficients and solvent viscosity. RTILs possessing $\left[\mathrm{NTf}_{2}\right]^{-}$and $[\mathrm{FAP}]^{-}$anions showed the highest microelectrode peak currents for the oxidation in $\mathrm{H}_{2}$ saturated solutions, with $\left[\mathrm{C}_{4} \mathrm{mim}\right]\left[\mathrm{NTf}_{2}\right]$ being the most sensitive. The large number of available RTIL anion/cation pairs allows scope for the possible electrochemical detection of hydrogen gas for use in gas-sensor technology. 


\section{Keywords}

Hydrogen, Room Temperature Ionic Liquids, Electrochemical Oxidation, Cyclic Voltammetry

\section{Introduction}

Room temperature ionic liquids (RTILs) are liquids composed entirely of ions and exist in the liquid state near room temperature. They have several charactersitic properties, including intrinsic conductivity, low (or near zero) volatility, high polarity, high thermal stability and wide electrochemical windows. They are increasingly being used in applications such as green synthesis, $[1,2]$ catalysis with transition metals, [3] and in electrochemical applications such as electrodeposition of metals, [4] as electrolytes in lithium batteries, [5] sensors, [6] capacitors, [7] and in solar cells. [8] The interested reader is directed to a number of recent reviews describing electrochemistry in ionic liquids. [9-11]

RTILs are currently being investigated as possible electrolytes for gas sensing applications, [6] since their favourable properties (low-volatility and high thermal stability) means the sensor does not dry out, and provides the possibility for gas sensing at high temperatures, which may be of use in the combustion industry and elsewhere. A range of gases have so far been investigated in RTILs, including $\mathrm{O}_{2},[12] \mathrm{CO}_{2}$ [13] (from $\mathrm{O}_{2}$ and $\mathrm{CO}_{2}$ simultaneously), $\mathrm{H}_{2},[14]$ $\mathrm{NH}_{3},[15,16] \mathrm{SO}_{2}[17,18]$ and $\mathrm{NO}_{2} \cdot[19]$

The focus of the present paper is the electrochemical oxidation of hydrogen gas, which is of major importance in fuel cells [20] and other applications. Several reports have looked at the $\mathrm{H}_{2}$ oxidation process in both protic [21-24] and aprotic $[25,26]$ solvents. Recently, we extended this study by looking at the electro-oxidation of $\mathrm{H}_{2}$ in a limited range of RTILs [14] in order to shed light on the nature of proton-ionic liquid interactions, and noted some interesting observations. First, an increase of the peak current for $\mathrm{H}_{2}$ oxidation was observed when the electrode was pre- 
anodized ("activated") at a potential more positive than the peak. A similar effect had also been noted in aprotic solvents in the presence of $\mathrm{H}_{2}$ on Pt electrodes. [25] Second, after activating the electrode for one minute, the voltammetry became much more electrochemically reversible. The activation step was necessary prior to recording voltammetric scans, in order to obtain reliable and reproducible peak potentials. After activation of the electrode, the following observations were noted: in $\left[\mathrm{C}_{2} \mathrm{mim}\right]\left[\mathrm{NTf}_{2}\right]$ and $\left[\mathrm{C}_{4} \mathrm{mim}\right]\left[\mathrm{NTf}_{2}\right]$, electrochemically reversible behaviour was seen, suggesting that the solvated proton is stable and easily reduced to $\mathrm{H}_{2}$. In $\left[\mathrm{N}_{6,2,2,2}\right]\left[\mathrm{NTf}_{2}\right]$ and $\left[\mathrm{P}_{14,6,6,6}\right]\left[\mathrm{NTf}_{2}\right]$, more quasi-reversible behaviour was seen. The voltammetry in $\left[\mathrm{C}_{6} \mathrm{mim}\right] \mathrm{Cl}$ was chemically irreversible on the timescale of the experiment, suggesting the formation of $\mathrm{HCl}$ or, more likely, $\left[\mathrm{HCl}_{2}\right]^{-}$. In $\left[\mathrm{C}_{4} \mathrm{mim}\right][\mathrm{OTf}],\left[\mathrm{C}_{4} \mathrm{mim}\right]\left[\mathrm{BF}_{4}\right]$ and $\left[\mathrm{C}_{4} \mathrm{mim}\right]\left[\mathrm{PF}_{6}\right]$, intermediate characteristics were seen. [14]

Building on this study, we have now investigated the $\mathrm{H}_{2}$ oxidation process in detail at activated Pt electrodes in ten ionic liquids with a diverse range of different anions and cations (the structures of which are given in Figure 1). The $\mathrm{H}_{2}$ oxidation potential has been reported vs a standard internal redox couple for all ten RTILs, and the effect of temperature on the voltammetry has been investigated in four RTILs. The results presented below may have implications in the electrochemical detection of $\mathrm{H}_{2}$ gas (particularly at higher temperatures), in understanding the nature of proton-ionic liquid environments, and ultimately helping to define a pH scale in RTIL media. 


\section{Experimental}

\subsection{Chemical Reagents}

1-Ethyl-3-methylimidazolium bis(trifluoromethylsulfonyl)amide $\left(\left[\mathrm{C}_{2} \mathrm{mim}\right]\left[\mathrm{NTf}_{2}\right]\right)$, 1-butyl-3-methylimidazolium bis(trifluoromethylsulfonyl)amide $\left(\left[\mathrm{C}_{4} \mathrm{mim}\right]\left[\mathrm{NTf}_{2}\right]\right)$ and their bromide salt precursors were prepared by standard literature procedures. [27] 1-Hexyl-3-methylimidazolium chloride $\left(\left[\mathrm{C}_{6} \mathrm{mim}\right] \mathrm{Cl}\right)$ was also prepared according to previous literature methods. [27] n-Hexyltriethylammonium bromide (Aldrich, 99\%) and tris(n-hexyltetradecyl)phosphonium chloride (Cytec) were used as purchased for metathesis with lithium bis(trifluoromethylsulfonyl)amide, and subsequently purified by standard literature procedures $[27]$ to yield $\left[\mathrm{N}_{6,2,2,2}\right]\left[\mathrm{NTf}_{2}\right]$ and $\left[\mathrm{P}_{14,6,6,6}\right]\left[\mathrm{NTf}_{2}\right]$ respectively. 1-Butyl-3-methylimidazolium tetrafluoroborate $\left(\left[\mathrm{C}_{4} \mathrm{mim}\right]\left[\mathrm{BF}_{4}\right]\right.$, high purity), 1butyl-3-methylimidazolium hexafluorophosphate $\left(\left[\mathrm{C}_{4} \mathrm{mim}\right]\left[\mathrm{PF}_{6}\right]\right.$, high purity) and 1-butyl-3methylimidazolium trifluoromethylsulfonate $\left(\left[\mathrm{C}_{4} \mathrm{mim}\right][\mathrm{OTf}]\right.$, high purity) were kindly donated by Merck KGaA. $\left[\mathrm{C}_{4} \mathrm{mim}\right]\left[\mathrm{BF}_{4}\right]$ and $\left[\mathrm{C}_{4} \mathrm{mim}\right]\left[\mathrm{PF}_{6}\right]$ were used as received. $\left[\mathrm{C}_{4} \mathrm{mim}\right][\mathrm{OTf}]$ was first diluted with $\mathrm{CH}_{2} \mathrm{Cl}_{2}$ and passed through a column consisting of alternating layers of neutral aluminium oxide and silica gel in order to remove residual acidic impurities. The synthesis of 1-butyl-3-methylimidazolium nitrate $\left(\left[\mathrm{C}_{4} \mathrm{mim}\right]\left[\mathrm{NO}_{3}\right]\right)$ was adapted from a previously published procedure. [28] $\mathrm{AgNO}_{3}(5.36 \mathrm{~g}, 0.032 \mathrm{M})$ and $\left[\mathrm{C}_{4} \mathrm{mim}\right] \mathrm{Cl}(5.00 \mathrm{~g}, 0.029 \mathrm{M})$ were dissolved separately in minimum amounts of ultrapure water. The $\left[\mathrm{C}_{4} \mathrm{mim}\right] \mathrm{Cl}$ solution was then slowly added to the stirred $\mathrm{AgNO}_{3}$ solution. After stirring overnight the solution was filtered to remove the $\mathrm{AgCl}$ precipitate, the water removed and the IL dried under high vacuum at $70{ }^{\circ} \mathrm{C}$ overnight. The IL was then dissolved in $400 \mathrm{~mL}$ dry methanol, small amounts of activated charcoal and acidic alumina were added as seeds for the remaining $\mathrm{AgCl}$, and the solution left overnight in a freezer. This solution was then filtered and the process repeated. The methanol was removed, and the ionic liquid was dried under high vacuum conditions. The possibility of some 
colloidal $\mathrm{Al}_{2} \mathrm{O}_{3}$ being introduced by this procedure cannot be discounted, but this material is not electroactive under the conditions studied. Voltammetric measurements on the purified liquid showed no indication of the presence of $\mathrm{Ag}^{+}$impurities. 1-Hexyl-3-methylimidazolium tris(perfluoroethyl)trifluorophosphate $\left(\left[\mathrm{C}_{6} \mathrm{mim}\right][\mathrm{FAP}]\right)$ was synthesized as described in the literature. [29] The success of the above procedures in purifying the ionic liquids was sensitively assessed by means of voltammetric measurements on blank solvents. A typical scan is shown in Figure 2 as a dotted line. In all cases, no unexpected voltammetric features were observed within the potential window of the particular solvent. Ferrocene $\left(\mathrm{Fe}\left(\mathrm{C}_{5} \mathrm{H}_{5}\right)_{2}, \mathrm{Fc}\right.$, Aldrich, $98 \%)$, cobaltocenium hexafluorophosphate $\left(\mathrm{Co}\left(\mathrm{C}_{5} \mathrm{H}_{5}\right)_{2} \mathrm{PF}_{6}, \mathrm{Cc}^{+}\right.$, Acros Organics, 98\%) tetra$n$-butylammonium perchlorate (TBAP, Fluka, Puriss electrochemical grade, <99\%), acetonitrile (Fischer Scientific, dried and distilled, <99.99\%) were used as received, without further purification. Hydrogen gas (99.995\% pure) was purchased from BOC gases, Manchester, UK.

\subsection{Instrumental}

All electrochemical experiments were performed using a computer-controlled $\mu$-Autolab potentiostat (Eco-Chemie, Netherlands). The electrochemistry of $\mathrm{H}_{2}$ gas was performed in a T-cell (reported previously), $[14,30]$ using a Pt microdisk (10 $\mu \mathrm{m}$ diameter) as the working electrode, and a silver wire as a quasi-reference electrode. The working electrode was modified with a section of disposable micropipette tip, into which $20 \mu \mathrm{L}$ of the blank RTIL solvent was placed. The liquid was purged under vacuum for ca. 90 minutes, after which gas was introduced through one arm of the cell. An outlet gas line led from the cell into a fume cupboard. Before voltammetric scans were undertaken, the ionic liquid was saturated with gas (typically for 10-15 minutes) as evidenced by stable maximum peak currents. For experiments involving cobaltocenium hexafluorophosphate $\left(\mathrm{Cc}^{+}\right)$as a redox probe, a solution of $20 \mathrm{mM} \mathrm{Cc}^{+}$was first made up in $5 \mathrm{~mL}$ MeCN. $20 \mu \mathrm{L}$ of this solution was then added to $20 \mu \mathrm{L}$ blank RTIL 
inside the T-cell, allowing evaporation of MeCN to leave $20 \mathrm{mM} \mathrm{Cc}^{+}$in the RTIL. Hydrogen gas was then introduced in the same way as described above. Experiments using the $\mathrm{Cc}^{+} / \mathrm{Cc}$ redox couple (where $\left.\mathrm{Cc}=\mathrm{CoC}_{5} \mathrm{H}_{5}\right)_{2}$ ) as a model redox system were conducted to ensure that the measurements were largely free of ohmic drop complications; the simulated voltammograms showed formal potentials and standard electrochemical rate constants which did not vary systematically with scan rate. These simulations, along with the related ferrocene/ferrocenium couple will be reported elsewhere. [31]

For all experiments, before each voltammetric scan, the electrode was preanodized/activated for 30 seconds at a chosen potential (typically $+2 \mathrm{~V}$, but lower for those RTILs with a smaller anodic window). The period of activation was significantly longer than that needed for the electrode to become activated in all of the RTILs studied. Temperature controlled experiments were performed in a thermostated box (previously described by Evans et al.) [32] which also functioned as a Faraday cage. The temperature was accurate to $\pm 0.5^{\circ} \mathrm{C}$.

The microdisk working electrode was polished on soft lapping pads (Buehler, Illinois) with an alumina slurry of size $1 \mu \mathrm{m}$ and $0.3 \mu \mathrm{m}$ respectively. The steady-state voltammetry of a 2 mM solution of Fc in acetonitrile containing 0.1 M TBAP was used to calculate the electrode diameter, adopting a value for the diffusion coefficient of $2.3 \times 10^{-9} \mathrm{~m}^{2} \mathrm{~s}^{-1}$ at $298 \mathrm{~K}$. [33]

\subsection{Chronoamperometric Experiments}

Chronoamperometric transients were achieved using a sample time of $0.001 \mathrm{~s}$. Before the potential step, the electrode was pre-anodized/activated for 30 seconds at $+2.0 \mathrm{~V}$ vs $\mathrm{Ag}(+1.2$ $\mathrm{V}$ in $\left[\mathrm{C}_{4} \mathrm{mim}\right]\left[\mathrm{NO}_{3}\right]$ and $\left.\left[\mathrm{C}_{6} \mathrm{mim}\right] \mathrm{Cl}\right)$. The potential was then stepped to a chosen potential after the oxidative peak, and the current was measured for $0.5 \mathrm{~s}$ after pre-equilibration for 20 seconds. The software package Origin 7.0 (Microcal Software Inc.) was used to fit the experimental data. The equations proposed by Shoup and Szabo [34] (below) were imported into the non linear 
curve fitting function, and the computer was instructed to perform 100 iterations on the data, which are sufficient to give $D$ and $c$ within an error of $0.6 \%$.

$$
\begin{gathered}
I=-4 n F D c r_{\mathrm{d}} f(\tau) \\
f(\tau)=0.7854+0.8863 \tau^{-\frac{1}{2}}+0.2146 \exp \left(-0.7823 \tau^{-\frac{1}{2}}\right) \\
\tau=\frac{4 D t}{r_{\mathrm{d}}{ }^{2}}
\end{gathered}
$$

where $n$ is the number of electrons transferred, $F$ is the Faraday constant, $D$ is the diffusion coefficient, $c$ is the initial concentration of parent species, $r_{\mathrm{d}}$ is the radius of the disk electrode, and $t$ is the time.

The value for the radius (previously calibrated) was fixed, and a value for the diffusion coefficient and the product of the number of electrons multiplied by concentration was obtained after optimization of the experimental data. It is noted that chronoamperometric transients with current-time steps longer than 0.5 seconds showed adsorption effects and could not be fitted to the Shoup and Szabo expression above. 


\section{Results and discussion}

\subsection{Cyclic voltammetry for $\mathrm{H}_{2}$ oxidation}

The electrochemical oxidation of $\mathrm{H}_{2}$ was studied in a range of ionic liquids with different anions and cations on an activated Pt microdisk electrode of diameter $10 \mu \mathrm{m}$. Relevant cyclic voltammograms are included in the supplementary information or elsewhere, [14] but the results of these studies are discussed below. First, we focus on the voltammetry obtained for the oxidation of $\mathrm{H}_{2}$ in two RTILs $\left(\left[\mathrm{C}_{6} \mathrm{mim}\right]\left[\mathrm{NO}_{3}\right]\right.$ and $\left.\left[\mathrm{C}_{6} \mathrm{mim}\right][\mathrm{FAP}]\right)$ which have not been studied before. These RTILs were chosen due to their featureless electrochemical window in the potential range for hydrogen oxidation, and the different nature of the anion, likely showing different interactions with the electrogenerated proton formed from $\mathrm{H}_{2}$ oxidation.

Figure 2 shows typical cyclic voltammetry for the oxidation of 1 atm. $\mathrm{H}_{2}$ in $\left[\mathrm{C}_{4} \mathrm{mim}\right]\left[\mathrm{NO}_{3}\right]$ on a Pt microelectrode (diameter $10 \mu \mathrm{m}$ ) at a range of scan rates. Consistent with the voltammetry reported previously for $\mathrm{H}_{2}$ oxidation in RTILs, [14] a well-defined oxidative peak is observed in $\left[\mathrm{C}_{4} \mathrm{mim}\right]\left[\mathrm{NO}_{3}\right]$ which becomes more transient-shaped at higher scan rates, consistent with diffusional controlled behaviour at a microelectrode. On the reverse scan in Figure 2, the absence of a back-peak indicates that the electrogenerated $\mathrm{H}^{+}$interacts strongly with $\left[\mathrm{NO}_{3}\right]^{-}$ anions on the voltammetric timescale. This observation is very similar to that reported for the oxidation of hydrogen in $\left[\mathrm{C}_{6} \mathrm{mim}\right] \mathrm{Cl}[14]$ and $\mathrm{HCl}$ in $\left[\mathrm{C}_{4} \mathrm{mim}\right]\left[\mathrm{NTf}_{2}\right],[35]$ where clear evidence

of the formation of $\left[\mathrm{HCl}_{2}\right]^{-}$was reported. [35] For the oxidation of hydrogen in $\left[\mathrm{C}_{4} \mathrm{mim}\right]\left[\mathrm{NO}_{3}\right]$, $\mathrm{HNO}_{3}$ or $\mathrm{H}\left[\mathrm{NO}_{3}\right]_{2}{ }^{-}$are likely formed in a chemical step following the reaction, according to:

$$
\frac{1}{2} \mathrm{H}_{2}-e^{-} \rightleftharpoons \mathrm{H}^{+}
$$

and either/both of the following equations:

$$
\mathrm{H}^{+}+\mathrm{NO}_{3}^{-} \rightarrow \mathrm{HNO}_{3}
$$




$$
\mathrm{H}^{+}+2 \mathrm{NO}_{3}^{-} \rightarrow \mathrm{H}\left[\mathrm{NO}_{3}\right]_{2}^{-}
$$

Clear physical evidence of the formation of the hydrogen dinitrate ion has been reported previously. [36]

Figure 3 shows cyclic voltammetry for the oxidation of $1 \mathrm{~atm} . \mathrm{H}_{2}$ on a $\mathrm{Pt}$ microelectrode (diameter $10 \mu \mathrm{m}$ ) at a range of scan rates in $\left[\mathrm{C}_{6} \mathrm{mim}\right][\mathrm{FAP}]$. The oxidation peak is more 'steadystate' in nature compared to the majority of the other ionic liquids studied (see SI), but the reduction peak is sharp and shows transient behaviour. Due to the presence of the reductive back-peak, the voltammetry appears to be chemically reversible, suggesting that the solvated proton, $\mathrm{H}^{+}$(solvated by $[\mathrm{FAP}]^{-}$ions but not chemically reacting with them), is stable and is reduced to $\mathrm{H}_{2}$ on the reverse sweep. As seen in Figure 3, the peak separation increases slightly with scan rate suggesting that the process is electrochemically quasi-reversible.

The voltammetry obtained from the remaining 8 RTILs studied is next briefly discussed and is included in the supplementary information. In $\left[\mathrm{C}_{2} \mathrm{mim}\right]\left[\mathrm{NTf}_{2}\right]$ and $\left[\mathrm{C}_{4} \mathrm{mim}\right]\left[\mathrm{NTf}_{2}\right]$, electrochemically quasi-reversible behaviour was seen, and in $\left[\mathrm{N}_{6,2,2,2}\right]\left[\mathrm{NTf}_{2}\right]$ and $\left[\mathrm{P}_{14,6,6,6}\right]\left[\mathrm{NTf}_{2}\right]$, yet more quasi-electrochemically reversible behaviour was seen, as judged by larger peak to peak separations and scan rate dependence. The voltammetry in $\left[\mathrm{C}_{6} \mathrm{mim}\right] \mathrm{Cl}$ was chemically irreversible on the timescale of the experiment (as with $\left[\mathrm{C}_{4} \mathrm{mim}\right]\left[\mathrm{NO}_{3}\right]$ above), and (as with $\left.\left[\mathrm{C}_{6} \mathrm{mim}\right][\mathrm{FAP}]\right)$, in $\left[\mathrm{C}_{4} \mathrm{mim}\right][\mathrm{OTf}],\left[\mathrm{C}_{4} \mathrm{mim}\right]\left[\mathrm{BF}_{4}\right]$ and $\left[\mathrm{C}_{4} \mathrm{mim}\right]\left[\mathrm{PF}_{6}\right]$, intermediate characteristics were seen. For all ten ionic liquids, the peak potentials for the oxidation and reduction peak, and their separations will be discussed later in section 3.3.

Plots of peak current vs square root scan rate were approximately linear for all ten RTILs studied (least-squares correlation coefficient, $\mathrm{R}^{2}$, greater than 0.950 ) but typically do not pass through the origin because the magnitude of the diffusion coefficients have characteristics which lead to voltammetry intermediate of micro/macro-electrode behaviour. This can be explained 
by considering the following inequality:

$$
\nu \leq \frac{R T D}{n F r_{\mathrm{d}}^{2}}
$$

where $\nu$ represents scan rate, $R$ is the universal gas constant, $T$ is the absolute temperature, $D$ is the diffusion coefficient, $F$ is the Faraday constant and $r_{\mathrm{d}}$ the radius of the disk. For true steady-state behaviour on a disk electrode, equation 7 must apply. Therefore, taking a typical diffusion coefficient of $1 \times 10^{-10} \mathrm{~m}^{2} \mathrm{~s}^{-1}$ for hydrogen gas diffusing in an RTIL (see next section), a scan rate of less than ca. $50 \mathrm{mV} \mathrm{s}^{-1}$ is necessary for true microelectrode behaviour. For most of the scan rates studied in this report, the anticipated voltammetric behaviour is intermediate between cases of pure micro- and macro-electrode. Accordingly, although the peak currents increase with scan rate, they do not show a direct proportionality of the peak current vs square root scan rate, as is commonly used to fingerprint diffusion controlled processes in macro-electrode voltammetry. However, in the case of $\mathrm{H}_{2}$ oxidation in $\left[\mathrm{C}_{6} \mathrm{mim}\right] \mathrm{Cl}$, a plot of peak current $v s$ square root scan rate does pass through the origin (see supplementary information) suggesting a smaller diffusion coefficient, which is consistent with the results presented in the next section.

\subsection{Potential Step Chronoamperometry}

In addition to studying the cyclic voltammetry of $\mathrm{H}_{2}$ oxidation, a potential step was performed on the oxidative wave in order to try to calculate diffusion coefficients and solubilities of hydrogen in each RTIL. It has previously been reported [14] that potential step transients (of duration 10 seconds) for $\mathrm{H}_{2}$ oxidation in several ionic liquids could not be analysed due to severe adsorption effects. However, when the time-step was significantly reduced (to 0.5 seconds), a transient was obtained which could be successfully fit to the Shoup and Szabo expression [34] based on diffusion controlled currents. Figure 4 shows a chronoamperometric transient (solid 
line) and the fitted theoretical data from the Shoup and Szabo expression (dots) for the oxidation of 1 atm. $\mathrm{H}_{2}$ in $\left[\mathrm{C}_{4}\right.$ mim $]\left[\mathrm{NO}_{3}\right]$ on a $\mathrm{Pt}$ microelectrode of diameter $10 \mu \mathrm{m}$. From analysis of the transient, and assuming the following 2-electron process applies: [14]

$$
\mathrm{H}_{2}-2 e^{-}+2 \mathrm{~A}^{-} \rightarrow 2 \mathrm{HA}
$$

(where $\mathrm{A}^{-}=$solvent anion), a diffusion coefficient of $1.0( \pm 0.1) \times 10^{-10} \mathrm{~m}^{2} \mathrm{~s}^{-1}$ and a concentration/solubility of $4.8( \pm 0.3) \mathrm{mM}$ was obtained. This diffusion coefficient is comparable in magnitude to that of oxygen in several RTILs, [12] but $c a .1$ order of magnitude larger than solid diffusing species in RTILs (c.f. $3.35 \times 10^{-11} \mathrm{~m}^{2} \mathrm{~s}^{-1}$ for ferrocene in $\left.\left[\mathrm{C}_{2} \mathrm{mim}\right]\left[\mathrm{NTf}_{2}\right]\right)$. [37] This process was then repeated for the oxidation of $\mathrm{H}_{2}$ in all RTILs studied, and the experimental and fitted theoretical data is shown in the supplementary information. The numerical data is shown in Table 1, along with the dynamic viscosities $(\eta)$ of each RTIL. According to the Stokes-Einstein relation [38] in equation 9, for a simple diffusing species, a linear relationship is expected between the diffusion coefficients $(D)$ and the inverse of viscosity:

$$
D=\frac{k T}{6 \eta \pi \alpha}
$$

where $k$ is the Boltzmann constant, $T$ is the temperature and $\alpha$ is the hydrodynamic radius of the diffusing species. This relationship is commonly followed in conventional molecular solvents, and also for organic molecules in RTILs. [32] A plot of $D$ vs $1 / \eta$ using the values in Table 1 is presented in Figure 5, and shows no apparent linear relationship, suggesting that $\mathrm{H}_{2}$ is far too small a molecule for equation 9 to apply. The diffusion coefficients of hydrogen in RTILs are approximately 1-2 orders of magnitude smaller than that obtained in conventional protic and aprotic solvents (see Table 2) which is not unreasonable, considering the higher viscosity of the RTILs $(34-7453 \mathrm{cP})$ compared to that of water $(1.00 \mathrm{cP})$, dimethyl sulfoxide $(2.20 \mathrm{cP})$, dimethylformamide $(0.92 \mathrm{cP})$ and pyridine $(0.95 \mathrm{cP})$ at $293 \mathrm{~K} .[39]$ 
The concentrations (solubilities) of hydrogen in all ten RTILs studied are relatively moderate (ca. 3-10 mM), and are approximately comparable to that of oxygen in RTILs (cf. $3.9 \mathrm{mM}$ in $\left[\mathrm{C}_{2} \mathrm{mim}\right]\left[\mathrm{NTf}_{2}\right]$ and $11.6 \mathrm{mM}$ in $\left.\left[\mathrm{N}_{6,2,2,2}\right]\left[\mathrm{NTf}_{2}\right]\right)$. [12] However, they are much higher than solubilities of hydrogen obtained by other researchers in RTILs using other methods. Several researchers [40-42] report the non-detectable hydrogen concentration at ambient temperatures and pressures due to high viscosity and low gas solubility, and resort to the use of higher temperatures [40] and higher pressures [42] to detect low amounts of $\mathrm{H}_{2}$. Dyson et al. [43] report solubilities at $293 \mathrm{~K}$ and $1 \mathrm{~atm}$. of $c a .0 .7$ to $0.9 \mathrm{mM}$. These have been included in Table 2, together with solubilities reported in water and other aprotic solvents. [25] As can clearly be seen by comparing the solubilities in Table 2 to Table 1 (from this work), the electrochemical method is shown to be much more sensitive, and can detect lower concentrations of hydrogen. Therefore, this method shows great promise for the analytical determination of hydrogen concentrations in Clark-cell type gas sensors. [6]

Since the $D$ and $c$ values vary somewhat with the solvent, the product of the two variables was then calculated in each ionic liquid, and the numbers are included in Table 1 . The ionic liquid with the highest $D c$ will give the highest current response (since the steady-state current at a microdisk is proportional to $D c)[6,34]$ and will therefore be the most suitable medium for sensing via the Clark-cell approach. By comparing the numbers in Table 1, it is evident that some ionic liquids will give higher attainable currents than others. In particular, all four $\left[\mathrm{NTf}_{2}\right]^{-}$ionic liquids and $\left[\mathrm{C}_{6} \mathrm{mim}\right][\mathrm{FAP}]$ have $D c$ values greater than 20 , suggesting that they are the most suitable media for hydrogen sensing, with $\left[\mathrm{C}_{4} \mathrm{mim}\right]\left[\mathrm{NTf}_{2}\right]$ being the most sensitive. $\left[\mathrm{C}_{4} \mathrm{mim}\right][\mathrm{OTf}],\left[\mathrm{C}_{4} \mathrm{mim}\right]\left[\mathrm{BF}_{4}\right],\left[\mathrm{C}_{4} \mathrm{mim}\right]\left[\mathrm{NO}_{3}\right]$ and $\left[\mathrm{C}_{4} \mathrm{mim}\right]\left[\mathrm{PF}_{6}\right]$ give intermediate current responses, and the ionic liquid which gives the lowest current response for $\mathrm{H}_{2}$ oxidation is $\left[\mathrm{C}_{6} \mathrm{mim}\right] \mathrm{Cl}$. This is not unexpected given the highly viscous nature of this liquid and the expected slow rate of mass transport. 


\section{3 $\quad \mathrm{H}_{2}$ Oxidation Potential vs Internal Reference Couple}

For all ten ionic liquids studied, the oxidation of $1 \mathrm{~atm} . \mathrm{H}_{2}$ was next studied in the presence of ca. $20 \mathrm{mM}$ cobaltocenium hexafluorophosphate $\left(\mathrm{CcPF}_{6}\right.$, where $\left.\mathrm{Cc}^{+}=\left(\mathrm{C}_{5} \mathrm{H}_{5}\right)_{2} \mathrm{Co}^{+}\right)$as an internal reference. The $\mathrm{Cc}^{+} / \mathrm{Cc}$ redox couple has been recommended by the International Union of Pure and Applied Chemistry (IUPAC) as one of several stable reference couples in aprotic solvents and has been used by Bond et al. [44] in RTILs this context. By obtaining peak potentials of $\mathrm{H}_{2}$ oxidation $v s \mathrm{Cc}^{+} / \mathrm{Cc}$, it is thought that this may indicate (if formal potentials can be inferred) the relative acid/base properties of the solvent, which, at present, is relatively unknown in ionic liquids.

Figure 6 shows the oxidation of 1 atm. $\mathrm{H}_{2}$ in the presence of $c a .20 \mathrm{mM} \mathrm{Cc}^{+}$on a $10 \mu \mathrm{m}$ diameter Pt electrode at a range of scan rates in (a) $\left[\mathrm{C}_{2} \mathrm{mim}\right]\left[\mathrm{NTf}_{2}\right]$, (b) $\left[\mathrm{C}_{4} \mathrm{mim}\right]\left[\mathrm{NTf}_{2}\right]$, (c) $\left[\mathrm{C}_{4} \mathrm{mim}\right]\left[\mathrm{BF}_{4}\right]$ and $(\mathrm{d})\left[\mathrm{C}_{4} \mathrm{mim}\right][\mathrm{OTf}]$. The voltammograms for the remaining six ionic liquids are given in the supplementary information. As can clearly be seen, the oxidation peaks of $\mathrm{H}_{2}$ are well separated from the $\mathrm{Cc}^{+} / \mathrm{Cc}$ redox couple, allowing for the measurement of $\mathrm{H}_{2}$ peak potentials relative to the $\mathrm{Cc}^{+} / \mathrm{Cc}$ redox couple. However, it is noted that the peak currents for $\mathrm{H}_{2}$ oxidation decreased slightly (by ca. 5-30\%) compared to the peak currents of $\mathrm{H}_{2}$ alone, suggesting a reaction of hydrogen with cobaltocenium hexafluorophosphate or its reduction product. [45] A similar reaction with hydrogen in RTILs was also observed in the presence of $\mathrm{N}, \mathrm{N}, \mathrm{N}^{\prime}, \mathrm{N}^{\prime}$-tetramethylphenylenediamine, TMPD. [46] Table 3 shows the peak potential for the oxidation of $\mathrm{H}_{2}$ relative to the $\mathrm{Cc}^{+} / \mathrm{Cc}$ redox couple in all ten RTILs studied. A large variation in $\mathrm{H}_{2}$ oxidation potential is observed. This reflects both kinetics $\left(\Delta E_{\mathrm{pp}}\right)$ and thermodynamics $\left(E_{\mathrm{f}}{ }^{0}\right)$; these will be discussed separately below.

In an attempt to obtain thermodynamic data from the voltammetry, we have analysed those cases in which the back-peak is likely directly related to the $\mathrm{H}_{2}$ oxidation product (but 
not those in which there is a suggestion of follow-up chemistry) to give the mid peak potential of the $\mathrm{H}^{+} /$"HA" couple. Note however that since the voltammograms show characteristics intermediate between those of macro/micro electrodes, this procedure is approximate, and on the basis of full simulations in the RTIL $\left[\mathrm{C}_{4} \mathrm{mim}\right]\left[\mathrm{PF}_{6}\right]$; we estimate the likely error being no more than $\pm 0.15 \mathrm{mV}$. A subsequent publication may address the issue of extracting kinetic and thermodynamic parameters from voltammetry in this intermediate region. The mid-point potentials, $E_{\mathrm{f}}{ }^{0}$, are reported in the final column of Table 3 . The values for the four $\left[\mathrm{NTf}_{2}\right]^{-}$ ionic liquids are relatively consistent at $c a .1 .36 \mathrm{~V}$, and are significantly larger than the value of $0.98 \mathrm{~V}$ in $\left[\mathrm{C}_{4} \mathrm{mim}\right][\mathrm{OTf}]$, and smaller than that obtained in $\left[\mathrm{C}_{4} \mathrm{mim}\right]\left[\mathrm{PF}_{6}\right](1.53 \mathrm{~V})$. This suggests that there is a stronger interaction of the electrogenerated proton with $[\mathrm{OTf}]^{-}$compared to $\left[\mathrm{NTf}_{2}\right]^{-}$, which is not unexpected, as $\mathrm{HNTf}_{2}$ is as a stronger acid than HOTf. The larger peak separation in $\left[\mathrm{C}_{4} \mathrm{mim}\right]\left[\mathrm{PF}_{6}\right]$ is unexpected, but is consistent with a previous study on the oxidation of ammonia in RTILs, [16] where the oxidation potential of $\mathrm{NH}_{3}$ vs $\mathrm{Cc}^{+} / \mathrm{Cc}$ was found to be larger than in $\left[\mathrm{NTf}_{2}\right]^{-},[\mathrm{OTf}]^{-}$and $\left[\mathrm{BF}_{4}\right]^{-}$based ionic liquids.

Table 3 also shows the peak potentials of the "HA" (where $\mathrm{A}^{-}=$solvent anion) reduction peak vs $\mathrm{Cc}^{+} / \mathrm{Cc}$, and the resulting peak separations of the $\mathrm{H}_{2} /$ "HA" couple $\left(\Delta E_{\mathrm{pp}}\right)$. The ionic liquids giving the smallest peak separations suggest that the $\mathrm{H}_{2} / \mathrm{H}^{+}$couple is the least electrochemically irreversible in these media, or that the protonated anion is easiest to reduce. Therefore, it is seen that the process is more electrochemically reversible (but not fully reversible) in $\left[\mathrm{C}_{2} \mathrm{mim}\right]\left[\mathrm{NTf}_{2}\right]$ and $\left[\mathrm{C}_{4} \mathrm{mim}\right]\left[\mathrm{NTf}_{2}\right]$, followed by $\left[\mathrm{C}_{6} \mathrm{mim}\right][\mathrm{FAP}],\left[\mathrm{C}_{4} \mathrm{mim}\right]\left[\mathrm{PF}_{6}\right]$, $\left[\mathrm{C}_{4} \mathrm{mim}\right][\mathrm{OTf}]$ and $\left[\mathrm{N}_{6,2,2,2}\right]\left[\mathrm{NTf}_{2}\right]$, and the largest separations are observed in $\left[\mathrm{C}_{4} \mathrm{mim}\right]\left[\mathrm{BF}_{4}\right]$ and $\left[\mathrm{P}_{14,6,6,6}\right]\left[\mathrm{NTf}_{2}\right]$. For $\left[\mathrm{C}_{4} \mathrm{mim}\right]\left[\mathrm{BF}_{4}\right]$, the large separation may suggest the possibility for dissociation of the oxidation product, $\mathrm{H}\left[\mathrm{BF}_{4}\right]$, which is an observation which has been noted before. [47] The very large separation in $\left[\mathrm{P}_{14,6,6,6}\right]\left[\mathrm{NTf}_{2}\right]$ may suggest slower electrode kinetics; it is speculated that the slowness may arise for solvent structural reasons. One possibility is 
that the protons may be locally bound to the $\left[\mathrm{NTf}_{2}\right]^{-}$anions in a solvation shell, which is then surrounded by large $\left[\mathrm{P}_{14,6,6,6}\right]^{+}$cations, making the speed of the reduction of protons back to $\mathrm{H}_{2}$ more difficult. This may occur to a lesser extent in $\left[\mathrm{N}_{6,2,2,2}\right]\left[\mathrm{NTf}_{2}\right]$, where an intermediate peak separation was observed, as the carbon chain lengths are smaller than in $\left[\mathrm{P}_{14,6,6,6}\right]\left[\mathrm{NTf}_{2}\right]$. Another reason is that there may be strong adsorption of the large $\left[\mathrm{P}_{14,6,6,6}\right]^{+}$and $\left[\mathrm{N}_{6,2,2,2}\right]^{+}$ cations on the electrode surface, particularly if the potential is more negative than the potential of zero charge (PZC). This would also give the appearance of slower electrode kinetics. For the remaining ionic liquids with different anions, the intermediate values of $\Delta E_{\mathrm{pp}}$ may indicate intermediate electrode kinetics.

\subsection{Preliminary Temperature study for $\mathbf{H}_{2}$ Oxidation}

Due to the high thermal stability and near-zero volatility of RTIL solvents, they have several advantages over conventional protic and aprotic solvents, particularly when used as solvents in gas sensors at high temperatures, where conventional solvents may evaporate. The ability to perform voltammetric measurements at higher temperature is quantitatively useful, since voltammetric measurements at higher temperature are more sensitive, and the attainable limiting current is increased. For this reason, a preliminary temperature study (ca. 298-333 K) has been carried out in some of the ionic liquids mentioned above.

Figure 7 shows the oxidation of $1 \mathrm{~atm} . \mathrm{H}_{2}$ at a range of temperatures at $1 \mathrm{~V} \mathrm{~s}^{-1}$ on a $\mathrm{Pt}$ microelectrode (diameter $10 \mu \mathrm{m}$ ) in (a) $\left[\mathrm{C}_{4} \mathrm{mim}\right]\left[\mathrm{NO}_{3}\right]$, (b) $\left[\mathrm{C}_{2} \mathrm{mim}\right]\left[\mathrm{NTf}_{2}\right]$, (c) $\left[\mathrm{C}_{4} \mathrm{mim}\right]\left[\mathrm{NTf}_{2}\right]$ and (d) $\left[\mathrm{C}_{4} \mathrm{mim}\right][\mathrm{OTf}]$. In all cases, the peak current for $\mathrm{H}_{2}$ oxidation increases systematically with temperature. This is because the viscosity of the RTIL decreases with increasing temperature, and hence the rate of mass transport to the electrode surface is faster, resulting in larger peak currents. The peak separations of the forward and reverse peak appear to decrease as the temperature is increased, suggesting that HA (where $\mathrm{A}^{-}=$solvent anion) is more rapidly 
reduced to $\mathrm{H}_{2}$ at higher temperatures. The peak shapes become more steady-state in nature as the temperature increases. Steady-state behaviour is typically observed on microelectrodes in conventional molecular solvents, but the much higher viscosity of ionic liquids (1-3 orders of magnitude) means that diffusion coefficients are much smaller, and transient voltrammetric behaviour is common. [10] This is represented in Figure 7; as the temperature increases and the viscosity decreases, the peaks become more steady-state in nature. The reduction peak, however, is very sharp, and gets even sharper when the temperature is increased (particularly for the $\left[\mathrm{NTf}_{2}\right]^{-}$-based RTILs), suggesting that the diffusion coefficient of the solvated proton in RTILs is much lower than that of $\mathrm{H}_{2}$. This leads to voltammetry exhibiting both steady-state and transient behaviour in the same cycle, as observed for the oxygen/superoxide couple in RTILs. [12]

In order to determine if the solubilities and diffusion coefficients change with temperature, potential-step chronoamperometry was then performed on the hydrogen oxidation peak at all temperatures studied. However, the quality of fitting of the experimental data to the Shoup and Szabo expression [34] became systematically poor as the temperature was increased, and the data was deemed unreliable. Qualitatively, though, it can be seen from Figure 7 that the limiting currents are higher at increased temperatures. This increased sensitivity may prove to be an advantage when detecting hydrogen gas concentrations at higher temperatures.

\section{Conclusions}

The electrochemical oxidation of hydrogen has been studied in ten different ionic liquids. The results from this study revealed diffusion coefficients and solubilities of hydrogen in each ionic liquid, and there was no obvious relationship found between $D$ and viscosity, suggesting that $\mathrm{H}_{2}$ is too small a molecule for the Stokes-Einstein relation to apply. In addition, the oxidation 
potential of hydrogen has been reported against a standard internal reference couple, and a large variation in peak potentials was observed, which are thought to be mainly dependent on the nature of the anion and its interaction with the electrogenerated proton. A voltammetric study at increasing temperatures showed that the peak currents of $\mathrm{H}_{2}$ oxidation increased with temperature.

\section{Supplementary Information Available}

Cyclic voltammograms (in the absence and presence of $\mathrm{Cc}^{+}$), experimental and fitted theoretical chronoamperometric transients, and plots of peak current vs square root scan rate for the oxidation hydrogen on an activated $10 \mu \mathrm{m}$ Pt electrode in several RTILs. This material is available free of charge via the Internet at http://www.elsevier.com

\section{Acknowledgments}

D.S.S. thanks Schlumberger Cambridge Research and L.A. thanks the Department of Education and Learning in Northern Ireland and Merck GmBH for funding. The authors thank Emma I. Rogers for assistance in the simulation of $\mathrm{Cc}^{+} / \mathrm{Cc}$ voltammetry in several RTILs. 


\section{References}

[1] M. J. Earle, K. R. Seddon, Pure Appl. Chem. 72 (2000) 1391-1398.

[2] K. N. Marsh, A. Deev, A. C.-T. Wu, E. Tran, A. Klamt, Korean J. Chem. Eng. 19 (2002) 357-362.

[3] P. Wasserscheid, W. Keim, Angew. Chem. Int. Ed. 39 (2000) 3772-3789.

[4] F. Endres, ChemPhysChem 3 (2002) 144-154.

[5] P. C. Howlett, D. R. MacFarlane, A. F. Hollenkamp, Electrochem. Solid-State Lett. 7 (2004) A97-A101.

[6] M. C. Buzzeo, C. Hardacre, R. G. Compton, Anal. Chem. 76 (2004) 4583-4588.

[7] A. B. McEwen, E. L. Ngo, K. LeCompte, J. L. Goldman, J. Electrochem. Soc. 146 (1999) 1687-1695.

[8] P. Wang, S. M. Zakeeruddin, J.-E. Moser, M. Grätzel, J. Phys. Chem. B 107 (2003) 1328013285.

[9] D. S. Silvester, R. G. Compton, Z. Phys. Chem. 220 (2006) 1247-1274.

[10] M. C. Buzzeo, R. G. Evans, R. G. Compton, ChemPhysChem 5 (2004) 1106-1120.

[11] F. Endres, S. Zein El Abedin, PhysChemChemPhys 8 (2006) 2101-2116.

[12] M. C. Buzzeo, O. V. Klymenko, J. D. Wadhawan, C. Hardacre, K. R. Seddon, R. G. Compton, J. Phys. Chem. A 107 (2003) 8872-8878.

[13] M. C. Buzzeo, O. V. Klymenko, J. D. Wadhawan, C. Hardacre, K. R. Seddon, R. G. Compton, J. Phys. Chem. B 108 (2004) 3947-3954. 
[14] D. S. Silvester, L. Aldous, C. Hardacre, R. G. Compton, J. Phys. Chem. B 111 (2007) 5000-5007.

[15] M. C. Buzzeo, D. Giovanelli, N. S. Lawrence, C. Hardacre, K. R. Seddon, R. G. Compton, Electroanalysis 16 (2004) 888-896.

[16] X. Ji, D. S. Silvester, L. Aldous, C. Hardacre, R. G. Compton, J. Phys. Chem. C 111 (2007) 9562-9572.

[17] Q. Cai, Y.-z. Xian, H. Li, Y.-m. Zhang, J. Tang, L.-t. Jin, Huadong Shifan Daxue Xuebao, Ziran Kexueban (2001) 57-60.

[18] D. S. Silvester, E. I. Rogers, L. E. Barrosse-Antle, T. L. Broder, R. G. Compton, J. Braz. Chem. Soc. (2008) Accepted for publication.

[19] T. L. Broder, D. S. Silvester, L. Aldous, C. Hardacre, R. G. Compton, J. Phys. Chem. B 111 (2007) 7778-7785.

[20] R. O'Hayre, S.-W. Cha, W. Colella, F. B. Prinz, Fuel Cell Fundamentals, John Wiley and Sons: New York, 2005.

[21] V. P. Belokopytov, N. A. Aladzhalova, Elektrokhimiya 2 (1966) 1255-1262.

[22] A. Jaworski, M. Donten, Z. Stojek, J. G. Osteryoung, Anal. Chem. 71 (1999) 243-246.

[23] F. G. Will, J. Electrochem. Soc. 110 (1963) 145-151.

[24] B. E. Conway, D. M. Novak, J. Phys. Chem. 81 (1977) 1459-1468.

[25] J. Barrette, William C., D. T. Sawyer, Anal. Chem. 56 (1984) 653-657.

[26] S. Daniele, P. Ugo, G. A. Mazzocchin, G. Bontempelli, Anal. Chim. Acta 173 (1985) 141-148. 
[27] P. Bonhôte, A.-P. Dias, N. Papageorgiou, K. Kalyanasundaram, M. Grätzel, Inorg. Chem. 35 (1996) 1168-1178.

[28] L. Cammarata, S. G. Kazarian, P. A. Salter, T. Welton, PhysChemChemPhys 3 (2001) 5192-5200.

[29] N. Ignat'ev, U. Welz-Biermann, A. Kucheryna, G. Bissky, H. Willner, J. Fluorine Chem. 126 (8) (2005) 1150-1159.

[30] U. Schröder, J. D. Wadhawan, R. G. Compton, F. Marken, P. A. Z. Suarez, C. S. Consorti, R. F. de Souza, J. Dupont, New J. Chem. 24 (2000) 1009-1015.

[31] E. I. Rogers, D. S. Silvester, D. L. Poole, L. Aldous, C. Hardacre, R. G. Compton, J. Phys. Chem. C (2007) Accepted for publication.

[32] R. G. Evans, O. V. Klymenko, P. D. Price, S. G. Davies, C. Hardacre, R. G. Compton, ChemPhysChem 6 (2005) 526-533.

[33] M. Sharp, Electrochim. Acta 28 (1983) 301-308.

[34] D. Shoup, A. Szabo, J. Electroanal. Chem. Interfacial Electrochem. 140 (1982) 237-245.

[35] L. Aldous, D. S. Silvester, W. R. Pitner, R. G. Compton, M. C. Lagunas, C. Hardacre, J. Phys. Chem. C 111 (2007) 8496-8503.

[36] J. Roziere, M. T. Roziere-Bories, J. M. Williams, Inorg. Chem. 15 (1976) 2490-2494.

[37] N. Fietkau, A. D. Clegg, R. G. Evans, C. Villagrán, C. Hardacre, R. G. Compton, ChemPhysChem 7 (2006) 1041-1045.

[38] R. G. Compton, C. E. Banks, Understanding Voltammetry, World Scientific, Singapore, 2007. 
[39] D. R. Lide (Ed.), Handbook of Chemistry and Physics: 76th Edition, CRC Press, 1996.

[40] J. Kumelan, A. Pérez-Salado Kamps, D. Tuma, G. Maurer, J. Chem. Eng. Data 51 (2006) 11-14.

[41] J. L. Anthony, E. J. Maginn, J. F. Brennecke, J. Phys. Chem. B 106 (2002) 7315-7320.

[42] A. Berger, R. F. de Souza, M. R. Delgado, J. Dupont, Tetrahedron 12 (2001) 1825-1828.

[43] P. J. Dyson, G. Laurenczy, C. A. Ohlin, J. Vallance, T. Welton, Chem. Commun. (2003) 2418-2419.

[44] V. M. Hultgren, A. W. A. Mariotti, A. M. Bond, A. G. Wedd, Anal. Chem. 74 (2002) 3151-3156.

[45] Y. A. Kaplin, S. Chernyshova, L, G. V. Belysheva, I. F. Solov'ev, Khymiya i Khimicheskaya Tekhnologiya 20 (1977) 944-945.

[46] D. S. Silvester, E. I. Rogers, R. G. Compton, Reference Electrodes for use in RTILs, Wiley, 2008, Ch. 13.2. in "Electrodeposition in Ionic Liquid".

[47] C. Villagrán, M. Deetlefs, W. R. Pitner, C. Hardacre, Anal. Chem. 76 (2004) 2118-2123.

[48] O. O. Okoturo, T. J. VanderNoot, J. Electroanal. Chem. 568 (2004) 167-181.

[49] J. Sun, M. Forsyth, D. MacFarlane, J. Phys. Chem. B 102 (44) (1998) 8858-8864.

[50] K. R. Seddon, A. Stark, M.-J. Torres, ACS Symp. Ser. 819 (2002) 34-39.

[51] R. E. Del Sesto, C. Corley, A. Robertson, J. S. Wilkes, J. Organometallic Chem. 690 (2005) $2536-2542$. 
Table 1: Summary of the chronoamperometric data obtained from the electrochemical oxidation of hydrogen in different ionic liquids at $298 \mathrm{~K}$.

\begin{tabular}{lcccc} 
Ionic Liquid & $\eta$ at $293 \mathrm{~K} / \mathrm{cP}$ & $D_{\mathrm{H}_{2}} / \times 10^{-10} \mathrm{~m}^{2} \mathrm{~s}^{-1}$ & $c / \mathrm{mM}$ & $D c / \times 10^{-13} \mathrm{Mm}^{2} \mathrm{~s}^{-1}$ \\
\hline$\left[\mathrm{C}_{2} \mathrm{mim}\right]\left[\mathrm{NTf}_{2}\right]$ & $34[27]$ & $5.5( \pm 0.3)$ & $4.2( \pm 0.2)$ & 23.1 \\
{$\left[\mathrm{C}_{4} \mathrm{mim}\right]\left[\mathrm{NTf}_{2}\right]$} & $52[27]$ & $8.8( \pm 0.4)$ & $3.3( \pm 0.1)$ & 29.0 \\
{$\left[\mathrm{C}_{6} \mathrm{mim}\right][\mathrm{FAP}]$} & $74[29]$ & $3.4( \pm 0.2)$ & $6.6( \pm 0.4)$ & 23.8 \\
{$\left[\mathrm{C}_{4} \mathrm{mim}\right][\mathrm{OTf}]$} & $90[27]$ & $3.6( \pm 0.2)$ & $4.3( \pm 0.2)$ & 15.5 \\
{$\left[\mathrm{C}_{4} \mathrm{mim}\right]\left[\mathrm{BF}_{4}\right]$} & $112[48]$ & $2.2( \pm 0.1)$ & $5.2( \pm 0.1)$ & 11.4 \\
{$\left[\mathrm{~N}_{6,2,2,2}\right]\left[\mathrm{NTf}_{2}\right]$} & $167[49]$ & $3.2( \pm 0.3)$ & $7.2( \pm 0.4)$ & 23.0 \\
{$\left[\mathrm{C}_{4} \mathrm{mim}\right]\left[\mathrm{NO}_{3}\right]$} & $266[50]$ & $1.0( \pm 0.1)$ & $4.8( \pm 0.3)$ & 4.80 \\
{$\left[\mathrm{C}_{4} \mathrm{mim}\right]\left[\mathrm{PF}_{6}\right]$} & $371[50]$ & $1.5( \pm 0.3)$ & $5.1( \pm 0.2)$ & 7.65 \\
{$\left[\mathrm{P}_{14,6,6,6}\right]\left[\mathrm{NTf}_{2}\right]$} & $450[51]$ & $2.9( \pm 0.3)$ & $7.9( \pm 0.5)$ & 22.9 \\
{$\left[\mathrm{C}_{6} \mathrm{mim}\right] \mathrm{Cl}$} & $7453[29]$ & $0.13( \pm 0.02)$ & $9.7( \pm 0.5)$ & 1.26
\end{tabular}


Table 2: Summary of literature data for the solubilities (at 1 atm.) and diffusion coefficients of $\mathrm{H}_{2}$ in several different solvents. All data taken from Barrette and Sawyer [25] and Dyson et al. $[43]$

Solvent Solubility $\mathrm{H}_{2} / \mathrm{mM}$ Diffusion coefficient of $\mathrm{H}_{2} / \mathrm{m}^{2} \mathrm{~s}^{-1}$

\begin{tabular}{lcc}
\hline Water & 0.78 & $2.4 \times 10^{-9}$ \\
Dimethyl sulfoxide & 1.12 & $3.0 \times 10^{-9}$ \\
Dimethylformamide & 1.96 & $5.2 \times 10^{-9}$ \\
Pyridine & 2.00 & - \\
Methanol & 3.75 & - \\
Ethanol & 2.98 & - \\
Toluene & 3.50 & - \\
Benzene & 2.54 & - \\
Cyclohexane $^{-9}$ & 3.63 & - \\
{$\left[\mathrm{C}_{4}\right.$ mim $]\left[\mathrm{NTf}_{2}\right]$} & 0.77 & - \\
{$\left[\mathrm{C}_{4}\right.$ mim $][\mathrm{OTf}]$} & 0.97 & - \\
{$\left[\mathrm{C}_{4}\right.$ mim $][\mathrm{BF}$} & 0.86 & \\
{$\left[\mathrm{C}_{4}\right.$ mim $]\left[\mathrm{PF}_{6}\right]$} & 0.73 & -
\end{tabular}


Table 3: Peak potentials and separations at $298 \mathrm{~K}$ for the oxidation of $\mathrm{H}_{2}$ and the reduction of the solvated proton, "HA"§.

\begin{tabular}{|c|c|c|c|c|}
\hline Ionic Liquid & $\mathrm{Ox} \mathrm{H}_{2} * / \mathrm{V}$ & Red "HA"*§/V & $\Delta E_{\mathrm{pp}} / \mathrm{V}$ & $E_{\mathrm{f}}{ }^{0}$ of $\mathrm{H}^{+} /$"HA" $* \S / \mathrm{V}$ \\
\hline$\left[\mathrm{C}_{2} \operatorname{mim}\right]\left[\mathrm{NTf}_{2}\right]$ & 1.53 & 1.18 & 0.35 & 1.36 \\
\hline$\left[\mathrm{C}_{4} \mathrm{mim}\right]\left[\mathrm{NTf}_{2}\right]$ & 1.52 & 1.19 & 0.33 & 1.36 \\
\hline$\left[\mathrm{C}_{6} \mathrm{mim}\right][\mathrm{FAP}]$ & 2.45 & 1.94 & 0.51 & - \\
\hline$\left[\mathrm{C}_{4} \mathrm{mim}\right][\mathrm{OTf}]$ & 1.27 & 0.68 & 0.59 & 0.98 \\
\hline$\left[\mathrm{C}_{4} \mathrm{mim}\right]\left[\mathrm{BF}_{4}\right]$ & 1.36 & 0.36 & 1.00 & - \\
\hline$\left[\mathrm{N}_{6,2,2,2}\right]\left[\mathrm{NTf}_{2}\right]$ & 1.52 & 1.08 & 0.44 & 1.30 \\
\hline$\left[\mathrm{C}_{4} \mathrm{mim}\right]\left[\mathrm{NO}_{3}\right]$ & 0.82 & - & - & - \\
\hline$\left[\mathrm{C}_{4} \mathrm{mim}\right]\left[\mathrm{PF}_{6}\right]$ & 1.82 & 1.24 & 0.58 & 1.53 \\
\hline$\left[\mathrm{P}_{14,6,6,6}\right]\left[\mathrm{NTf}_{2}\right]$ & 2.02 & 0.73 & 1.29 & 1.38 \\
\hline$\left[\mathrm{C}_{6} \mathrm{mim}\right] \mathrm{Cl}$ & 0.87 & - & - & - \\
\hline
\end{tabular}

\footnotetext{
$\S_{\text {where }} \mathrm{A}^{-}=$solvent anion $\left(\left[\mathrm{NTf}_{2}\right]^{-},[\mathrm{FAP}]^{-},[\mathrm{OTf}]^{-},\left[\mathrm{BF}_{4}\right]^{-},\left[\mathrm{NO}_{3}\right]^{-},\left[\mathrm{PF}_{6}\right]^{-}\right.$or $\left.\mathrm{Cl}^{-}\right)$ *vs $\mathrm{Cc}^{+} / \mathrm{Cc}$ at $4 \mathrm{~V} \mathrm{~s}^{-1}$.
} 


\section{Figure Legends}

1. Structures of all the anions and cations employed in this study.

2. Cyclic voltammetry for the oxidation of 1 atm. $\mathrm{H}_{2}$ in $\left[\mathrm{C}_{4} \mathrm{mim}\right]\left[\mathrm{NO}_{3}\right]$ on a Pt electrode (diameter $=10 \mu \mathrm{m})$ at scan rates of $0.1,0.2,0.4,0.7,1,2$ and $4 \mathrm{~V} \mathrm{~s}^{-1}$. The electrode was activated at $+1.2 \mathrm{~V}$ for 30 seconds prior to each scan. A voltammogram of the blank RTIL with no added $\mathrm{H}_{2}$ is shown as a dotted line.

3. Cyclic voltammetry for the oxidation of 1 atm. $\mathrm{H}_{2}$ in $\left[\mathrm{C}_{6} \mathrm{mim}\right][\mathrm{FAP}]$ on a $\mathrm{Pt}$ electrode (diameter $=10 \mu \mathrm{m})$ at scan rates of $0.1,0.2,0.4,0.7,1$ and $2 \mathrm{~V} \mathrm{~s}^{-1}$. The electrode was activated at $+2.0 \mathrm{~V}$ for 30 seconds prior to all scans.

4. Experimental (-) and fitted theoretical (o) chronoamperometric transient obtained for the oxidation of 1 atm. $\mathrm{H}_{2}$ in $\left[\mathrm{C}_{4} \mathrm{mim}\right]\left[\mathrm{NO}_{3}\right]$ on a Pt electrode (diameter $10 \mu \mathrm{m}$ ). The potential was stepped from $-0.6 \mathrm{~V}$ to $+0.4 \mathrm{~V}$.

5. Plot of diffusion coefficient $(D)$ against the inverse of viscosity for the ten RTILs studied. $D$ values were obtained from theoretical fitting of chronoamperometric transients to the Shoup and Szabo expression. [34]

6. Cyclic voltammograms for the oxidation of 1 atm. $\mathrm{H}_{2}$ on a Pt electrode (diameter $=10 \mu \mathrm{m}$ ) in the presence of $c a .20 \mathrm{mM} \mathrm{Cc}{ }^{+}$in the RTILs: (a) $\left[\mathrm{C}_{2} \mathrm{mim}\right]\left[\mathrm{NTf}_{2}\right]$, (b) $\left[\mathrm{C}_{4} \mathrm{mim}\right]\left[\mathrm{NTf}_{2}\right]$,

(c) $\left[\mathrm{C}_{4} \mathrm{mim}\right]\left[\mathrm{BF}_{4}\right]$ and $(\mathrm{d})\left[\mathrm{C}_{4} \mathrm{mim}\right][\mathrm{OTf}]$ at scan rates of $0.1,0.2,0.4,0.7,1,2$ and $4 \mathrm{~V}$ $\mathrm{s}^{-1}$. In all cases, the electrode was activated at $+2 \mathrm{~V}$ for 30 seconds prior to each scan.

7. Cyclic voltammograms for the oxidation of 1 atm. $\mathrm{H}_{2}$ on a Pt electrode (diameter $=10$ $\mu \mathrm{m})$ at various temperatures in: (a) $\left[\mathrm{C}_{4} \mathrm{mim}\right]\left[\mathrm{NO}_{3}\right]$ at $298,303,308,313,318$ and $323 \mathrm{~K}$, (b) $\left[\mathrm{C}_{2} \mathrm{mim}\right]\left[\mathrm{NTf}_{2}\right]$ at $298,308,318$ and $328 \mathrm{~K}$, (c) $\left[\mathrm{C}_{4} \mathrm{mim}\right]\left[\mathrm{NTf}_{2}\right]$ at 303,313 and $323 \mathrm{~K}$ 
and $(\mathrm{d})\left[\mathrm{C}_{4} \mathrm{mim}\right][\mathrm{OTf}]$ at $303,313,323$ and $333 \mathrm{~K}$. Scan rate $1 \mathrm{~V} \mathrm{~s}^{-1}$. The electrode was activated at (a) $+1.2 \mathrm{~V},(\mathrm{~b})+2 \mathrm{~V},(\mathrm{c})+2 \mathrm{~V}$ and (d) $+2 \mathrm{~V}$ for 30 seconds prior to each scan. 


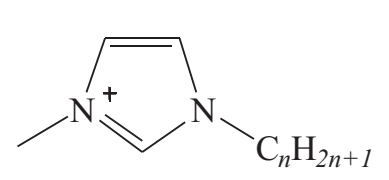

$\left[\mathrm{C}_{n} \operatorname{mim}\right]^{+}$<smiles>O=S(=O)([N-]S(=O)(=O)C(F)(F)F)C(F)(F)F</smiles>

$\left[\mathrm{NTf}_{2}\right]^{-}$

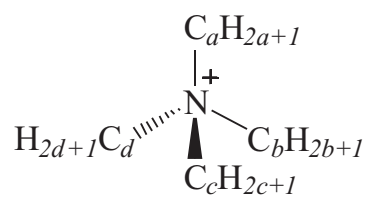

$\left[\mathrm{N}_{a, b, c, d}\right]^{+}$<smiles>F[B-](F)(F)F</smiles>

$\left[\mathrm{BF}_{4}\right]^{-}$

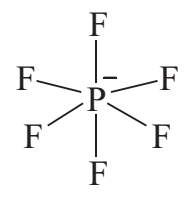

$\left[\mathrm{PF}_{6}\right]^{-}$

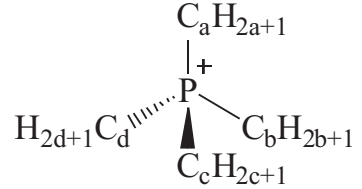

$\left[\mathrm{P}_{a, b, c, d}\right]^{+}$

Figure 1: Structures of all the anions and cations employed in this study. 


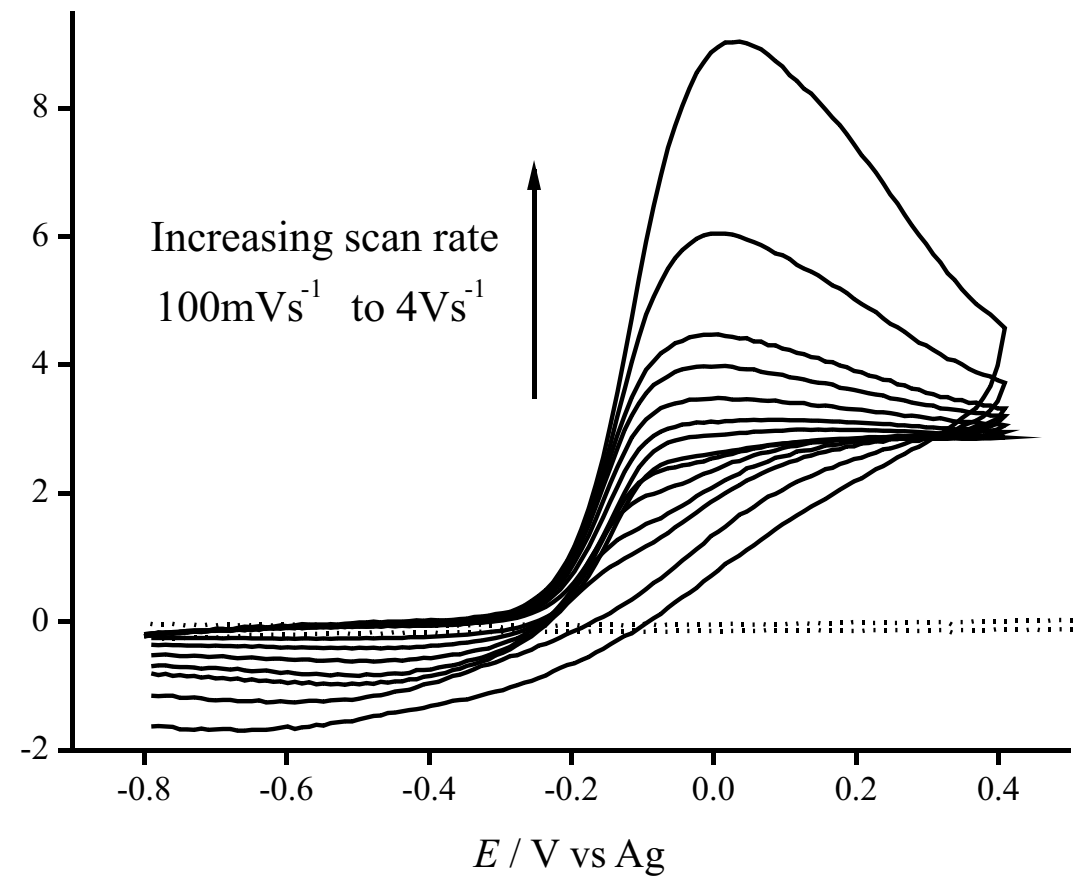

Figure 2: Cyclic voltammetry for the oxidation of 1 atm. $\mathrm{H}_{2}$ in $\left[\mathrm{C}_{4} \mathrm{mim}\right]\left[\mathrm{NO}_{3}\right]$ on a Pt electrode (diameter $=10 \mu \mathrm{m}$ ) at scan rates of $0.1,0.2,0.4,0.7,1,2$ and $4 \mathrm{~V} \mathrm{~s}^{-1}$. The electrode was activated at $+1.2 \mathrm{~V}$ for 30 seconds prior to each scan. A voltammogram of the blank RTIL with no added $\mathrm{H}_{2}$ is shown as a dotted line. 


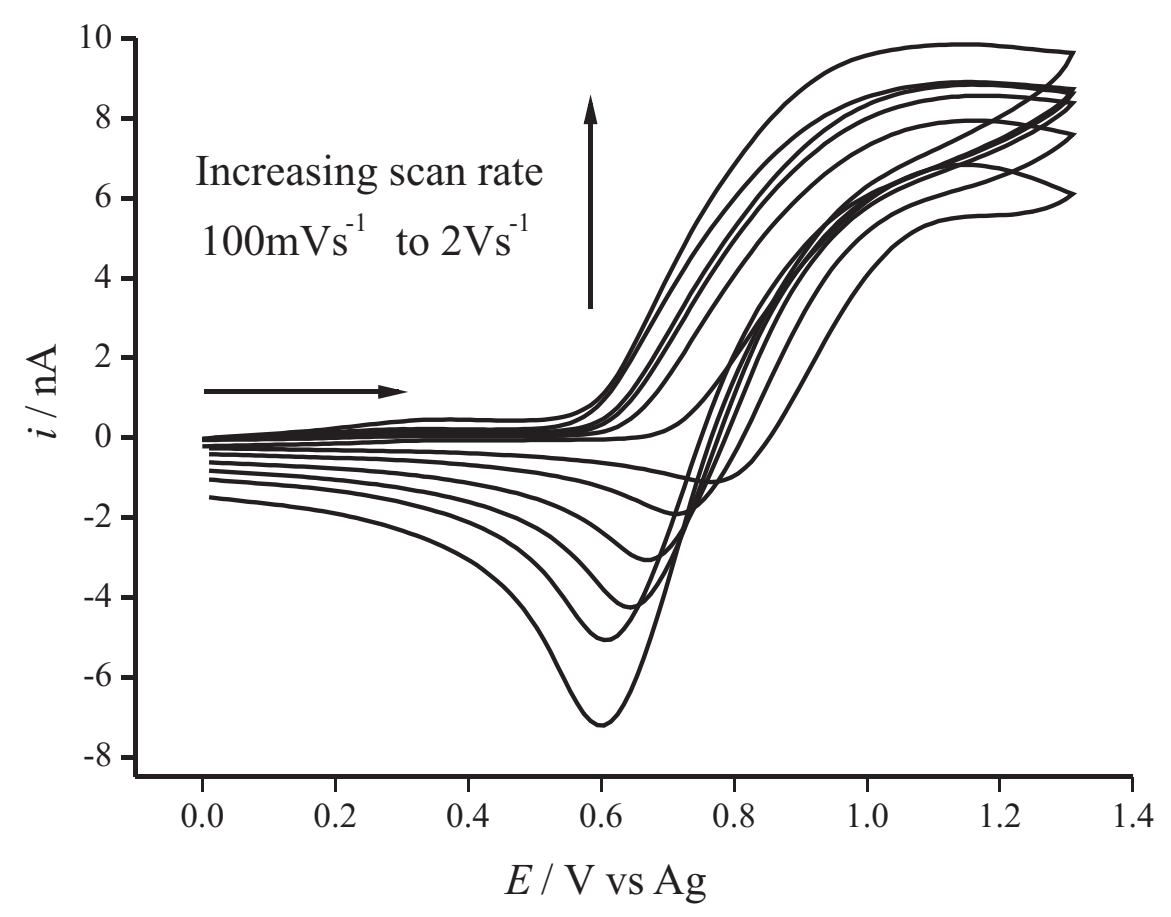

Figure 3: Cyclic voltammetry for the oxidation of 1 atm. $\mathrm{H}_{2}$ in $\left[\mathrm{C}_{6} \mathrm{mim}\right][\mathrm{FAP}]$ on a Pt electrode (diameter $=10 \mu \mathrm{m}$ ) at scan rates of $0.1,0.2,0.4,0.7,1$ and $2 \mathrm{~V} \mathrm{~s}^{-1}$. The electrode was activated at $+2.0 \mathrm{~V}$ for 30 seconds prior to all scans. 


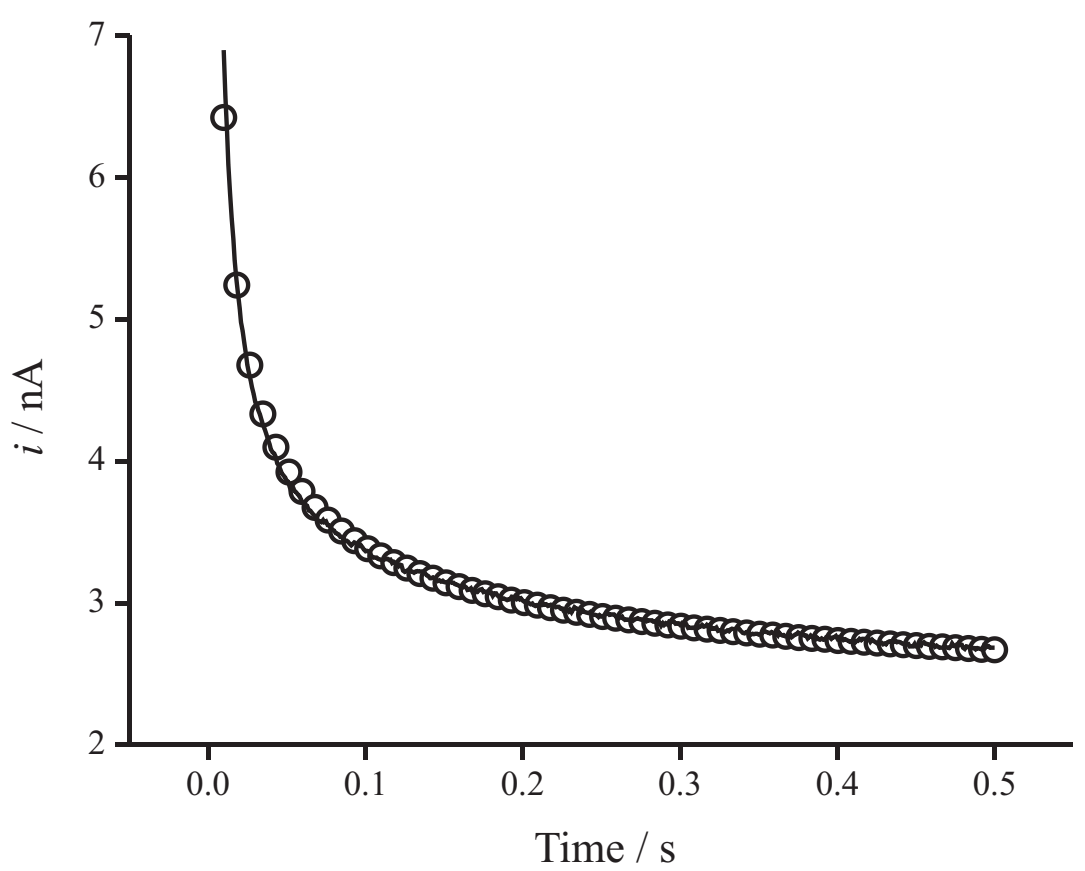

Figure 4: Experimental (-) and fitted theoretical (o) chronoamperometric transient obtained for the oxidation of $1 \mathrm{~atm} . \mathrm{H}_{2}$ in $\left[\mathrm{C}_{4} \mathrm{mim}\right]\left[\mathrm{NO}_{3}\right]$ on a Pt electrode (diameter $10 \mu \mathrm{m}$ ). The potential was stepped from $-0.6 \mathrm{~V}$ to $+0.4 \mathrm{~V}$. 


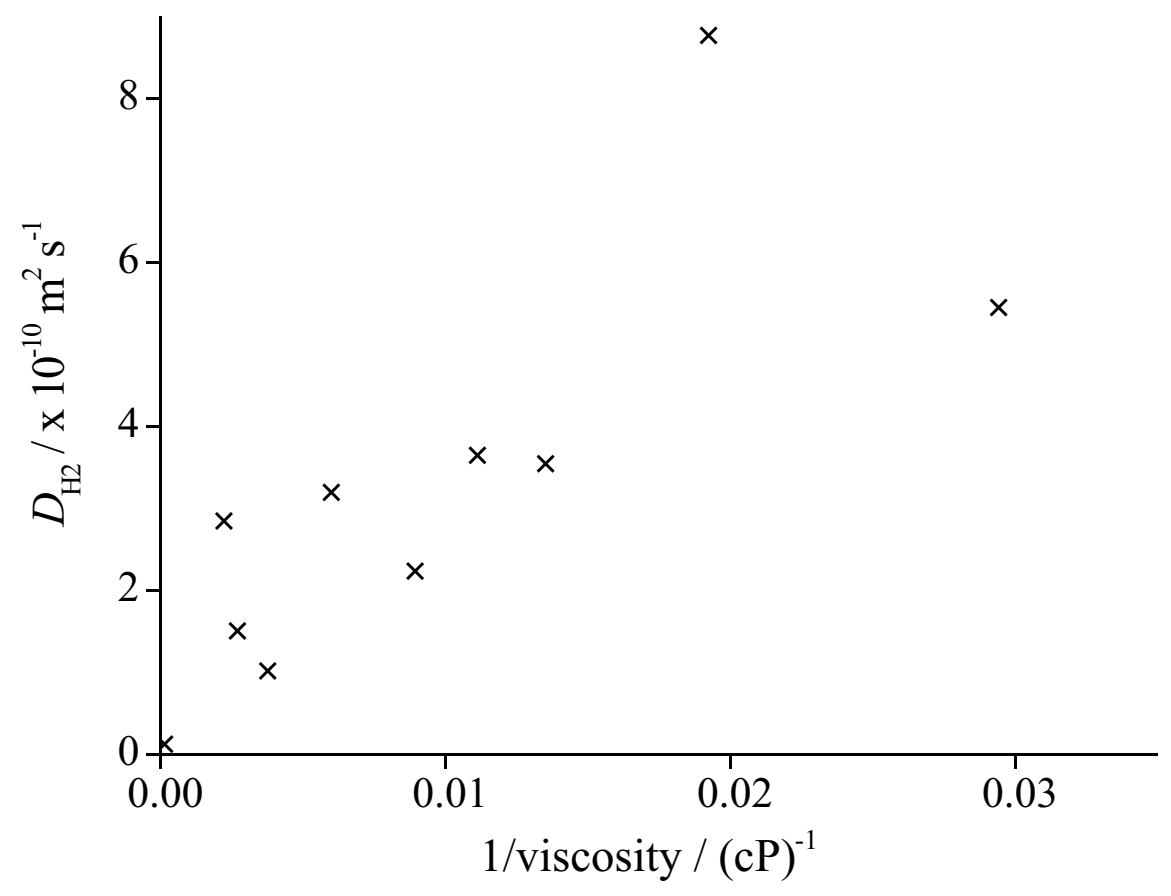

Figure 5: Plot of diffusion coefficient $(D)$ against the inverse of viscosity for the ten RTILs studied. $D$ values were obtained from theoretical fitting of chronoamperometric transients to the Shoup and Szabo expression. [34] 

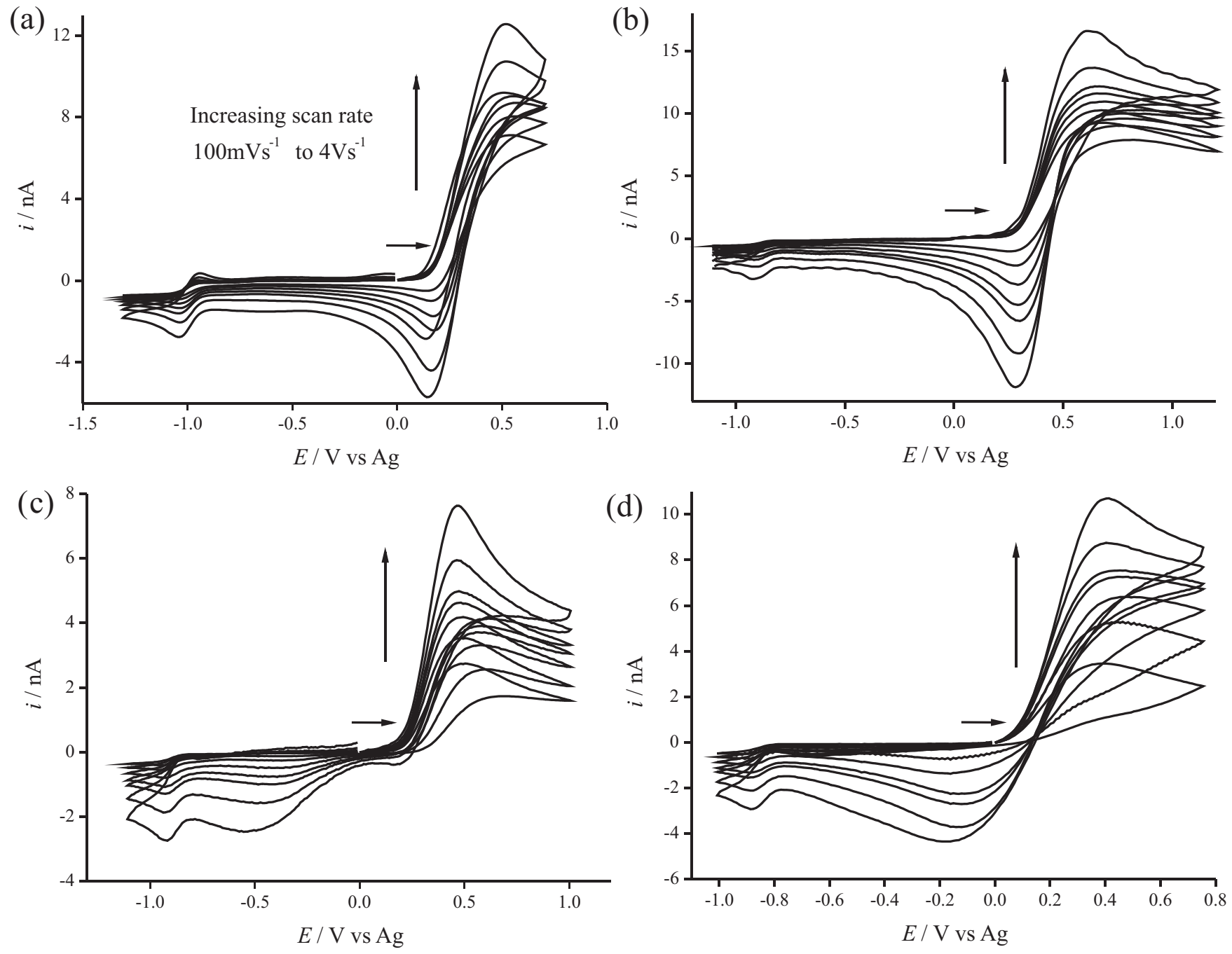

Figure 6: Cyclic voltammograms for the oxidation of $1 \mathrm{~atm} . \mathrm{H}_{2}$ on a Pt electrode (diameter=10 $\mu \mathrm{m}$ ) in the presence of $c a .20 \mathrm{mM} \mathrm{Cc}{ }^{+}$in the RTILs: (a) $\left[\mathrm{C}_{2} \mathrm{mim}\right]\left[\mathrm{NTf}_{2}\right]$, (b) $\left[\mathrm{C}_{4} \mathrm{mim}\right]\left[\mathrm{NTf}_{2}\right]$, (c) $\left[\mathrm{C}_{4} \mathrm{mim}\right]\left[\mathrm{BF}_{4}\right]$ and $(\mathrm{d})\left[\mathrm{C}_{4} \mathrm{mim}\right][\mathrm{OTf}]$ at scan rates of $0.1,0.2,0.4,0.7,1,2$ and $4 \mathrm{~V} \mathrm{~s}^{-1}$. In all cases, the electrode was activated at $+2 \mathrm{~V}$ for 30 seconds prior to each scan. 

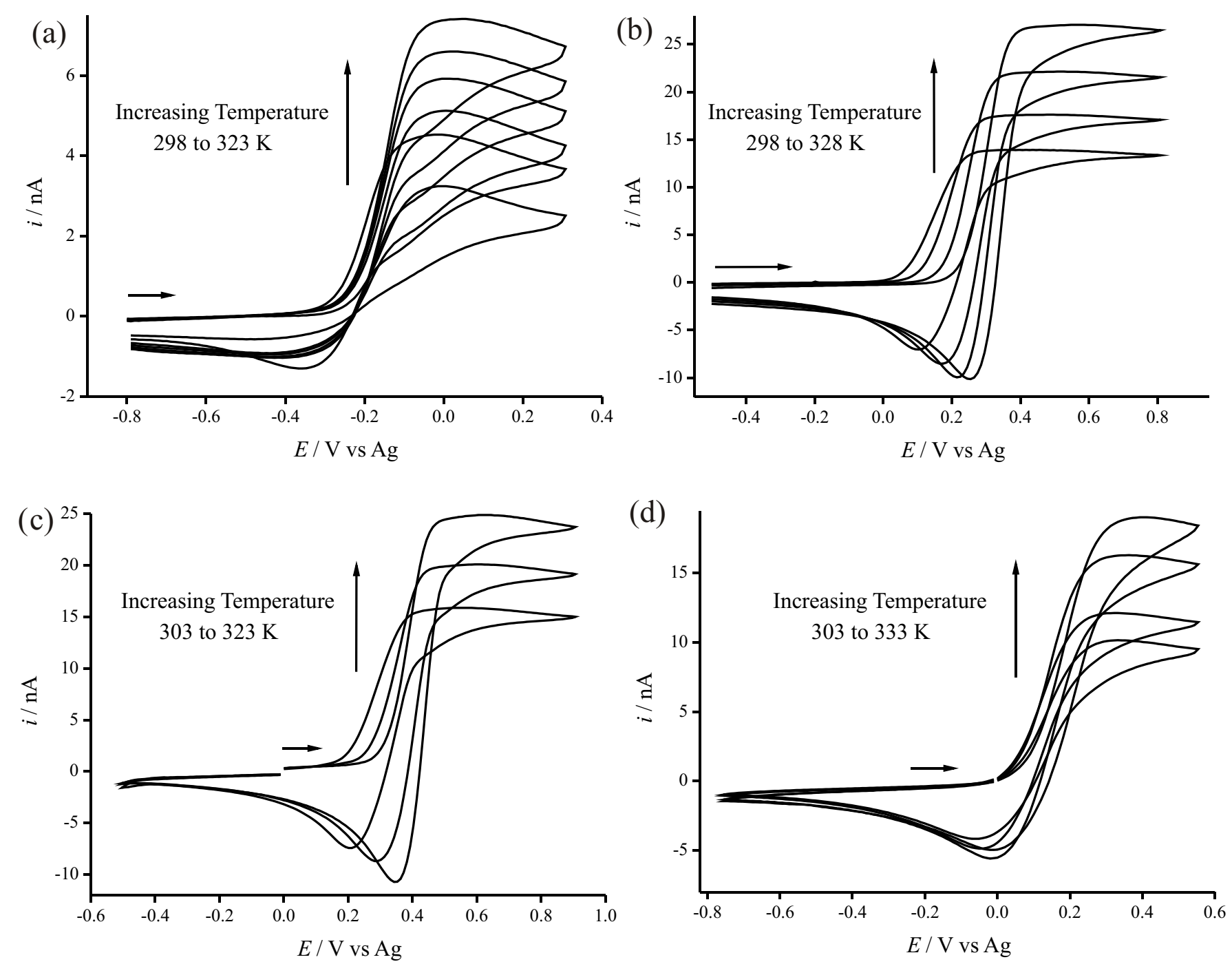

Figure 7: Cyclic voltammograms for the oxidation of $1 \mathrm{~atm} . \mathrm{H}_{2}$ on a Pt electrode (diameter=10 $\mu \mathrm{m}$ ) at various temperatures in: (a) $\left[\mathrm{C}_{4} \mathrm{mim}\right]\left[\mathrm{NO}_{3}\right]$ at 298, 303, 308, 313, 318 and $323 \mathrm{~K}$, (b) $\left[\mathrm{C}_{2} \operatorname{mim}\right]\left[\mathrm{NTf}_{2}\right]$ at $298,308,318$ and $328 \mathrm{~K},(\mathrm{c})\left[\mathrm{C}_{4} \mathrm{mim}\right]\left[\mathrm{NTf}_{2}\right]$ at 303,313 and $323 \mathrm{~K}$ and (d) $\left[\mathrm{C}_{4} \mathrm{mim}\right][\mathrm{OTf}]$ at $303,313,323$ and $333 \mathrm{~K}$. Scan rate $1 \mathrm{~V} \mathrm{~s}^{-1}$. The electrode was activated at (a) $+1.2 \mathrm{~V}$, (b) $+2 \mathrm{~V},(\mathrm{c})+2 \mathrm{~V}$ and (d) $+2 \mathrm{~V}$ for 30 seconds prior to each scan. 